\title{
A CLINICAL STUDY OF TRANSFUSION REACTIONS: THE HEMO- LYTIC EFFECT OF GROUP-O BLOOD AND POOLED PLASMA CONTAINING INCOMPATIBLE ISOAGGLUTININS
}

\author{
By R. V. EBERT ${ }^{1}$ and C. P. EMERSON, JR.1 \\ (From the European Theatre of Operations, U.S. Army)
}

(Received for publication January 8, 1946)

The stored blood employed during World War II for the treatment of battle casualties was almost exclusively group-O blood, in consequence of which patients of blood groups $A, B$ and $A B$ were obliged to receive incompatible isoagglutinins in the course of transfusion. Anti-A and anti-B isoagglutinins, incompletely absorbed in the process of pooling, were likewise contained in the dried plasma supplied by the Army. Thus, all patients of blood groups other than group $\mathrm{O}$ receiving pooled plasma, and over 50 per cent of those who were transfused with whole blood were subjected to the injection of incompatible isoagglutinins.

The preponderance of evidence in the literature indicates that the transfusion of group-O blood into recipients of other blood groups rarely produces serious reactions (1). The most extensive observations in this connection were reported by Aubert et al. (2), who described instances of chills, fever and evidences of blood destruction, but no serious complications following such transfusions. Reports of severe reactions in response to the injection of incompatible group-O blood have, however, appeared from time to time. A proper evaluation of such records in the earlier literature is difficult, because of the lack of data pertaining to $\mathrm{Rh}$ compatibility, but isolated cases have more recently been described ( 3 to 5 ) in which the $\mathrm{Rh}$ factor clearly could not be implicated. The present report is based on a detailed study of transfusion recipients, including 85 soldiers who received incompatible isoagglutinins in varying amounts. This investigation has been conducted for the purpose of determining in what manner and to what extent humans may react to the administration of whole blood and plasma containing these isoagglutinins, with the hope that such observations might yield data of practical

\footnotetext{
1 Major, M.C., A.U.S.
}

significance pertaining to the practice of transfusion therapy, or, possibly, of theoretical interest in relation to hemolytic processes in general.

\section{MATERIALS AND METHODS}

The sera of 184 blood donors were examined in order to estimate the relative frequency with which individuals of group-O blood are encountered who exhibit a high titer of isoagglutinins. These donors, selected at random, were all healthy adult males and females. Pooled washed erythrocytes of groups $\mathrm{A}$ and $\mathrm{B}$ were employed as the test cells, prepared in the form of a 2 per cent suspension in normal saline solution. Agglutination was read grossly and microscopically after centrifuging the test preparations. The titer values are expressed in terms of the final dilution following addition of the cell suspension, and the incidence of occurrence is recorded in Table I. Isoagglu-

TABLE I

Incidence of isoagglutinin titers determined in 184 group-O blood donors

\begin{tabular}{l|c|c|c|c|c|c|c|c}
\hline & $1: 4$ & $1: 8$ & $1: 16$ & $1: 32$ & $1: 64$ & $1: 128$ & $1: 256$ & $1: 512$ \\
\cline { 2 - 7 } Titer & \multicolumn{7}{c}{ Per cent of donors } \\
\cline { 2 - 8 } \begin{tabular}{c|c|c|c|c|c|c|c} 
Anti-A \\
Anti-B
\end{tabular} & 0.5 & 5 & 10 & 30 & 25 & 17 & 11 & 2 \\
\hline
\end{tabular}

tinin titers, determined in 5 lots of reconstituted pooled dried human plasma, selected at random, ranged from $1: 32$ to $1: 128$.

Differential counts of agglutinable and non-agglutinable erythrocytes in the blood were performed by the method of Ashby (6), modified to permit the use of dried anti-A and anti-B grouping sera (Lederle), a step which eliminated the factor of dilution by serum. The mixture of dried serum and cell suspension was centrifuged for 1 minute and subsequently allowed to stand for 5 minutes, following which the cells were resuspended. The nonagglutinated cells were counted in a standard hemocytometer, and this count compared with a similar count done on the cell suspension to which no grouping serum had been added. The reliability of this method was established through control counts performed on preparations containing $\mathrm{O}$ and $\mathrm{A}$ cells in known proportions.

Measurements of the plasma hemoglobin concentration were performed by the method of Bing and Baker (7), 
modified for the photoelectric cell colorimeter. Careful precautions were observed in obtaining plasma specimens for this determination. Three $\mathrm{ml}$. of blood were removed from a vein, using a $10 \mathrm{ml}$. syringe moistened with $2 \frac{1}{2}$ per cent sodium citrate solution, and introduced into a small test tube containing $0.4 \mathrm{ml}$. of $2 \frac{1}{2}$ per cent sodium citrate solution. The tube was then stoppered with a waxed cork and inverted once. Immediately thereafter it was centrifuged slowly for 5 minutes; the supernatant fluid was again centrifuged rapidly for 5 minutes, and this supernatant material employed for the determination. With this technique it was possible consistently to obtain values for plasma hemoglobin less than $2 \mathrm{mgm}$. per cent in normal subjects. In determining the concentration of serum or plasma bilirubin in specimens containing free hemoglobin, a correction factor was employed to eliminate an additive error due to the presence of hemoglobin.

Serum bilirubin concentrations were determined by the Van den Bergh method (8), modified for the Klett photoelectric cell colorimeter and standardized with purified bilirubin. The total hemoglobin concentration was measured colorimetrically with the Klett colorimeter. Hematocrits were read in $4 \mathrm{ml}$. tubes centrifuged at 2000 r.p.m. for 30 minutes, mixed ammonium and potassium oxalate being used as the anticoagulant. The method for estimating the osmotic fragility of erythrocytes depended upon the measurement of the percentage of total hemoglobin liberated by hemolysis in a mixture of 1 part whole blood with mixed oxalate, and 50 parts of the sodium chloride test solution, the hemoglobin concentration, in the supernatant solution being determined with the Klett colorimeter, and the percentage hemolysis, calculated therefrom, being charted with relation to the concentration of sodium chloride.

The plasma volume measurements were performed by the method of Gibson and Evelyn (9), modified to permit the determination of the dye concentrations in oxalated plasma (10), using the Klett colorimeter. In computing the red cell volume from the figures obtained for the plasma volume and hematocrit reading, a standard correction has routinely been applied, based on evidence (11, 12) that a systematic additive error of 15 per cent is inherent in this calculation.

The anticoagulant employed for all transfusions was sodium citrate.

$\mathrm{Rh}$ grouping tests reported in this communication were performed with potent human anti-Rh serum supplied through the kindness of Dr. Louis K. Diamond, Blood Grouping Laboratory, Boston, Mass.

\section{RESULTS}

\section{Transfusion reactions occurring after the admin- istration of blood containing incompatible iso- agglutinins in high titer.}

A few reactions were observed in patients receiving therapeutic blood transfusions, the explanation for which appeared to be related to the presence of a high concentration of incompatible isoagglutinins in the transfused blood. An instance of this type of reaction is given:

The patient, whose blood was group-A $\mathrm{Rh}+$ had received a gunshot wound of the right leg, following which he had been given 3 transfusions of whole blood. Two weeks later he received a transfusion of fresh group$\mathrm{O}$ blood. Twenty minutes after the transfusion was started, $350 \mathrm{ml}$. of blood having been injected, he began to complain of back pain, nausea, vomiting and chilliness. The transfusion was promptly halted. A specimen of urine obtained immediately after the reaction contained a moderate amount of hemoglobin, but subsequent samples were hemoglobin-free, and urine secretion remained undiminished. The plasma hemoglobin concentration immediately after the transfusion was $86 \mathrm{mgm}$. per $100 \mathrm{ml}$; two hours later it was $32 \mathrm{mgm}$. per $100 \mathrm{ml}$. The serum bilirubin concentration at the conclusion of the transfusion was $1.6 \mathrm{mgm}$. per $100 \mathrm{ml}$., at the end of two hours it was $3.7 \mathrm{mgm}$. per $100 \mathrm{ml}$, and after twelve hours it was $1.3 \mathrm{mgm}$. per $100 \mathrm{ml}$.

The patient recovered uneventfully, and subsequently received several transfusions of both group-O and groupA blood without further incident. Studies confirmed that the blood of the donor was group-O, and that of the recipient was group-A. The donor cells were not agglutinated or hemolyzed in vitro by the serum of the recipient, either at room temperature or after incubation at $37^{\circ} \mathrm{C}$. The titer of anti-A isoagglutinins in the plasma of the transfused blood was $1: 2048$. Ashby counts indicated that, prior to transfusion, 58 per cent of the patient's red cells were non-agglutinable, evidence that the previous transfusions had been of group-O blood. Twelve hours after the transfusion reaction the proportion of non-agglutinable cells was 75 per cent, indicating that the transfused cells almost certainly were not involved in the hemolytic process.

Interest in the features presented by this case prompted a subsequent investigation, conducted in an Evacuation Hospital, designed to study the incidence and clinical manifestations of this type of reaction. During the period of study, 265 transfusions of group-O blood were administered to 61 patients of groups A, B, or AB. There occurred 3 reactions which could be related to a high titer of incompatible isoagglutinins in the transfused material, representing an incidence of 1.1 per cent. The titer of isoagglutinins in the blood implicated in these reactions ranged from $1: 500$ to $1: 1500$, when the donor plasma was tested against the recipient cells. No similar reactions were observed with titers of less than $1: 500$.

The overt clinical manifestations of these reactions consisted of a brief chill and a moderate 
febrile response. Hemoglobinuria and marked hemoglobinemia were observed in one case. A transient slight elevation of plasma hemoglobin concentration was present in the other cases, but no hemoglobinuria developed. Hyperbilirubinemia, lasting from 12 to 24 hours, was consistently present, with icterus index elevations in no case exceeding 3 or 4 times the normal value. Serial Ashby counts indicated that the transfused cells were not destroyed with unusual rapidity; on the contrary, they could be demonstrated in unexpectedly high proportions in the blood of these patients following transfusion, suggesting that recipient red cells rather than donor cells had been destroyed.

Control studies were carried out in order to determine the effect of injecting incompatible plasma, in the absence of donor cells. Four healthy adult male volunteers, previously untransfused, whose blood groups were A or B, received single rapid intravenous injections of plasma derived from group-O blood, the isoagglutinin titers of which had been demonstrated to be unusually high. The titers determined in these plasma preparations, tested against the recipient red cells, in 1 case was between $1: 500$ and $1: 1000$, and, in the remaining instances, between $1: 2000$ and $1: 4000$. The volume of plasma injected ranged from $250 \mathrm{ml}$. to $500 \mathrm{ml}$.

No clinical symptoms were produced as a result of these transfusions, and only 1 subject exhibited a slight transient febrile response, the oral temperature rising to $99.3^{\circ} \mathrm{F}$. The effects of the injections on the levels of serum bilirubin, plasma hemoglobin and total hemoglobin concentrations are illustrated in Figure 1. In each case a slight rise in serum bilirubin concentration occurred, attaining a maximum in from 2 to 6 hours, and gradually subsiding to normal over a period of 12 to 24 hours. In 2 cases the plasma hemoglobin concentration rose to $10 \mathrm{mgm}$. per $100 \mathrm{ml}$., the peak concentrations developing within 30 minutes following the plasma injection, and the hemoglobinemia clearing completely in from 6 to 12

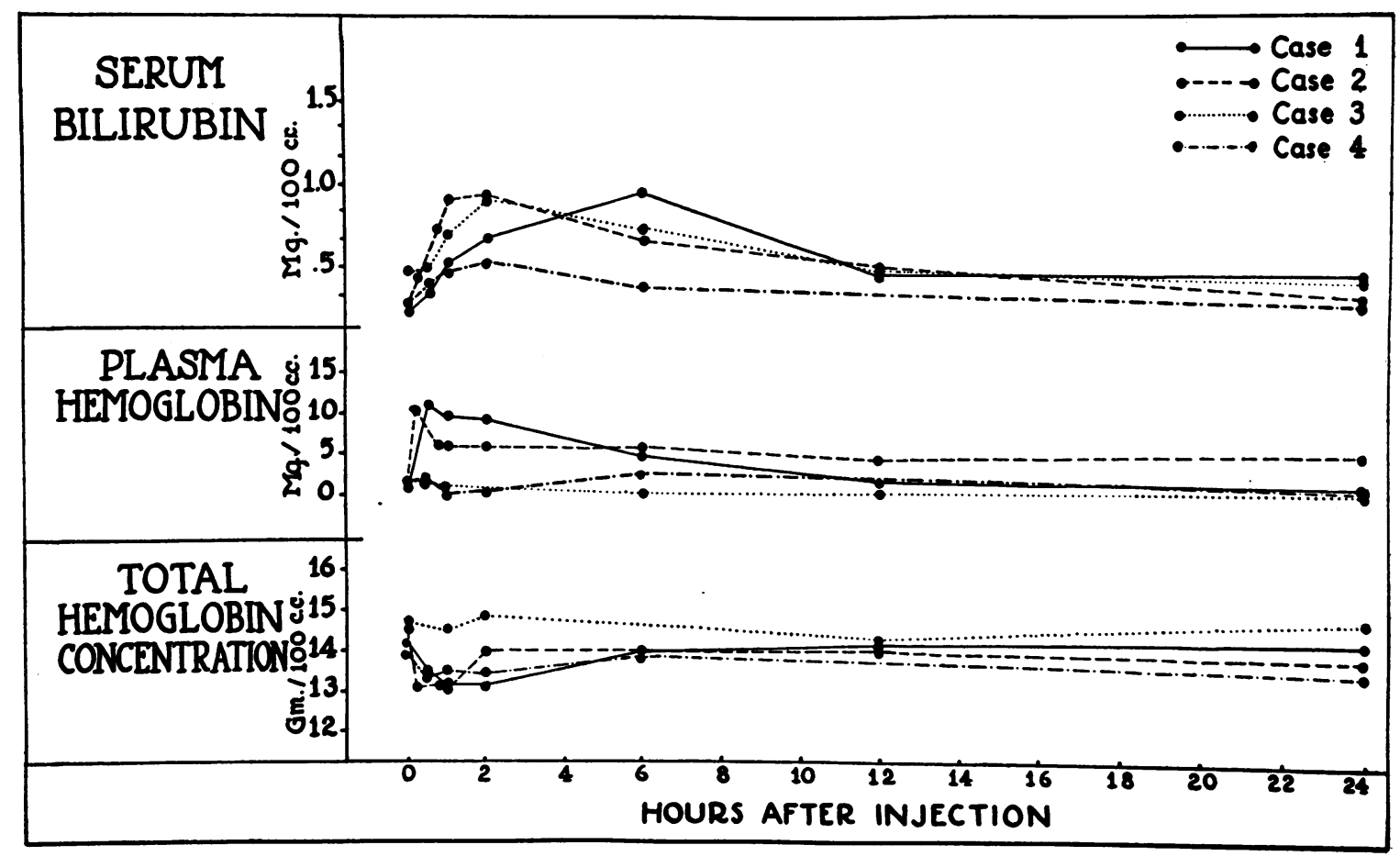

Fig. 1. The Effect of Plasma Containing a High Concentration of Incompatible Isoagglutinins, When Injected into Normal. Human Subjects

Two hundred and fifty to $500 \mathrm{ml}$. of plasma containing isoagglutinins in titers ranging from $1: 500$ to $1: 2000$ against the recipient cells were injected into four subjects whose blood groups were A or B. Note the definite increase in serum bilirubin and slight or absent elevation of plasma hemoglobin concentration. 
hours. No significant elevation of plasma hemoglobin concentration was observed in the remaining cases, and in no instance was hemoglobinuria encountered. The total hemoglobin concentration showed only a slight initial decline, consistent with the anticipated effect of erythro-dilution due to the injected plasma.

The results of these experimental plasma transfusions appeared to correspond qualitatively with the observations made in cases receiving therapeutic transfusions of whole blood containing a high concentration of incompatible isoagglutinins. To be sure, none of the 4 individuals receiving cell-free plasma exhibited a chill or other significant clinical symptomatology; nor was the apparent degree of blood destruction, judged on the basis of hemoglobinemia and bilirubinemia, equivalent to that occurring in some of the clinical cases in which there was a febrile response to group-O whole blood, despite the fact that the plasma recipients were presumed to have received as high a dosage of incompatible isoagglutinins as did those who reacted to the injection of whole blood. Whether this apparent disparity in quantitative effect may be attributable to the presence of red cells in the donor blood, or to an enhanced susceptibility on the part of those patients, was not determined. It is possible that the in vitro estimation of relative isoagglutinin potency is an inadequate measure of the hemolytic property of the material when introduced into the recipient.

The effects of single injections of cell-free hemoglobin solution.

In contrast to the findings in certain other hemolytic syndromes, the degree and duration of

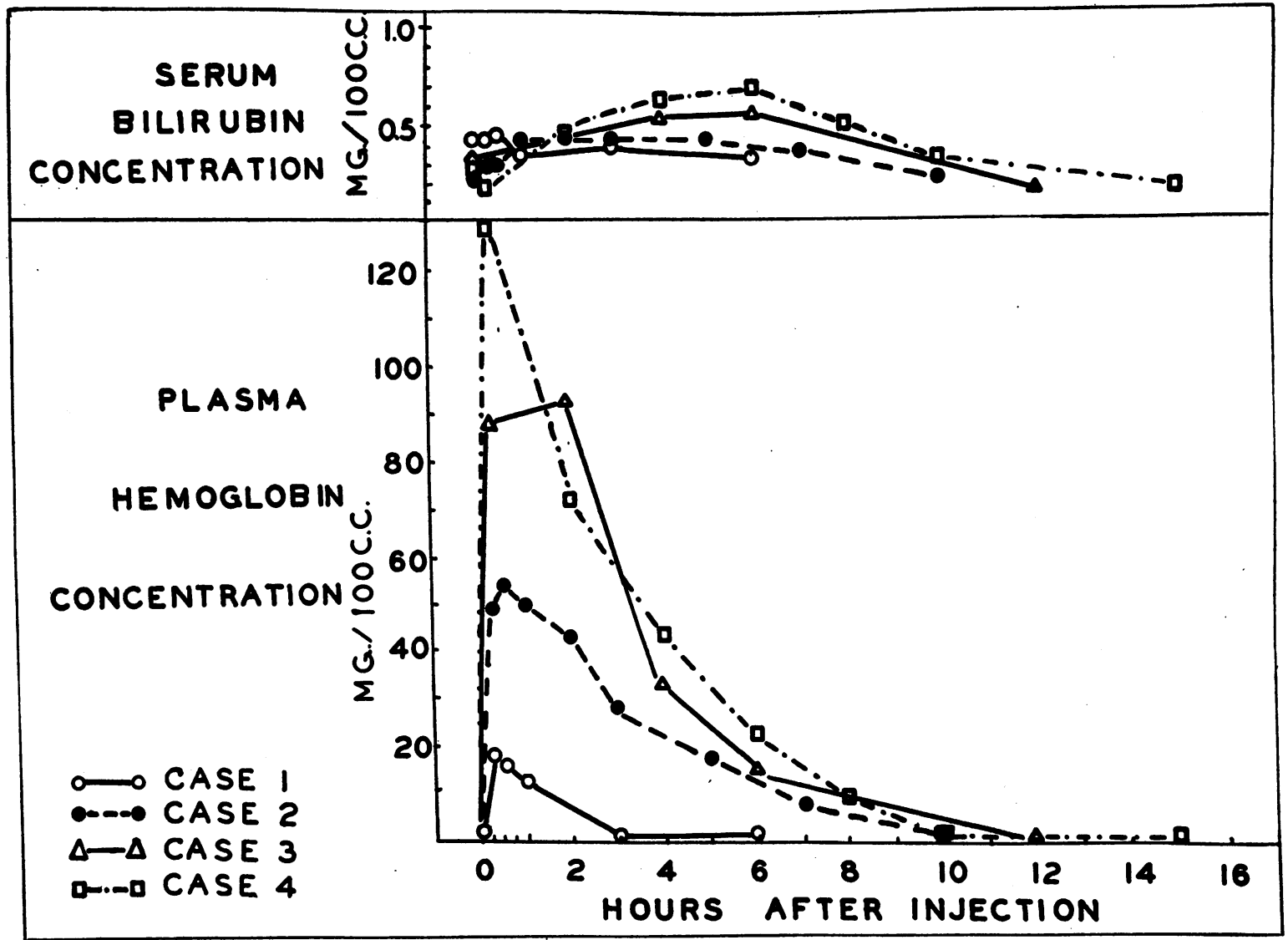

Fig. 2. The Effect of Injecting Hemoglobin Solution into Normal Human Subjects

Case 1 received 1.2 grams of hemoglobin intravenously; Case 2, 2.4 grams; Case 3, 4.0 grams; and Case 4, 6.2 grams. Note the relatively minor effect of these injections on the serum bilirubin concentration, in proportion to the marked hemoglobinemia produced. 
hyperbilirubinemia following the transfusion of incompatible isoagglutinins appeared to be disproportionately great compared to the degree of hemoglobinemia. A soldier with march hemoglobinuria, for example, was observed to have a plasma hemoglobin concentration of $40 \mathrm{mgm}$. per $100 \mathrm{ml}$. following a march which had induced hemoglobinuria; at the end of a 3-hour period of rest, at which time the urine was hemoglobin free, the plasma hemoglobin concentration was still approximately $10 \mathrm{mgm}$. per $100 \mathrm{ml}$. However, the maximum concentration of serum bilirubin, attained one hour following the march, was only $0.85 \mathrm{mgm}$. per $100 \mathrm{ml}$. A more striking clinical example illustrating the occurrence of marked hemoglobinemia, not followed by significant hyperbilirubinemia, was afforded by the case of a transfusion accident with recovery. Through error, a patient of blood group-O received $120 \mathrm{ml}$. of group-A blood. One hour following transfusion the plasma hemoglobin concentration was $240 \mathrm{mgm}$. per $100 \mathrm{ml}$; 8 hours later it was still $30 \mathrm{mgm}$. per $100 \mathrm{ml}$.; nevertheless, the peak level of bilirubinemia was less than $1.0 \mathrm{mgm}$. per 100 $\mathrm{ml}$. These inconsistencies of relationship between the concentrations of plasma hemoglobin and bilirubin prompted a series of experiments in which normal human subjects received varying amounts of cell-free hemoglobin intravenously, serial measurements of the plasma hemoglobin and serum bilirubin concentrations being performed following injection.

The recipients were normal young adult males who had volunteered to serve as subjects for these experiments. Hemoglobin solutions were prepared by lysing, in distilled water, a citrated specimen of whole blood obtained from the prospective recipient. The isotonicity of the hemolysate having been restored and the red-cell stroma precipitated by the addition of crystalline sodium chloride, the material was prepared for injection by passage through a Seitz filter. Injection of these solutions in no instance induced a febrile response or other unfavorable sequelae. Transient hemoglobinuria occurred in 1 subject (Case 4) who received 6.2 grams of hemoglobin, the lar-

TABLE II

The effect of group-O donor blood on the total volume of recipient red cells, in patients of blood groups $A$ and $B$

\begin{tabular}{|c|c|c|c|c|c|c|c|c|}
\hline \multirow{2}{*}{$\begin{array}{c}\text { Case (blood } \\
\text { group) }\end{array}$} & \multirow{2}{*}{$\begin{array}{c}\text { Volume of } \\
\text { group-O } \\
\text { blood } \\
\text { transfused }\end{array}$} & \multirow{2}{*}{ Time } & \multirow{2}{*}{ Hematocrit } & \multirow{2}{*}{$\begin{array}{l}\text { Plasma } \\
\text { volume }\end{array}$} & \multirow{2}{*}{$\begin{array}{l}\text { Non-agglu- } \\
\text { tinable red } \\
\text { cells }\end{array}$} & \multirow{2}{*}{$\begin{array}{c}\text { Volume of } \\
\text { group-O } \\
\text { cells } \\
\text { transfused }\end{array}$} & \multicolumn{2}{|c|}{ Change in volume* of } \\
\hline & & & & & & & $\begin{array}{c}\text { Group-O } \\
\text { cells }\end{array}$ & $\begin{array}{l}\text { Group-A or } \\
\text { B cells }\end{array}$ \\
\hline \multirow{2}{*}{$\left(\mathrm{ARh}^{1}+\right)$} & \multirow{2}{*}{$\begin{array}{c}m l . \\
1120\end{array}$} & before transfusion & 30.8 & $\begin{array}{c}m l . \\
2880\end{array}$ & $\begin{array}{c}\text { per cent } \\
1\end{array}$ & \multirow{2}{*}{$\begin{array}{l}m l . \\
470\end{array}$} & \multirow{2}{*}{$\begin{array}{l}m l . \\
450\end{array}$} & \multirow{2}{*}{$\begin{array}{c}m l . \\
-430\end{array}$} \\
\hline & & $48 \mathrm{hr}$. after transfusion & 28.5 & 3270 & 41 & & & \\
\hline \multirow{2}{*}{$\stackrel{2}{(\mathrm{ARh}+)}$} & \multirow{2}{*}{1560} & before transfusion & 31.2 & 2700 & 19 & \multirow{2}{*}{640} & \multirow{2}{*}{700} & \multirow{2}{*}{-560} \\
\hline & & $48 \mathrm{hr}$. after transfusion & 34.8 & 2600 & 76 & & & \\
\hline \multirow{2}{*}{$\stackrel{3}{\left(\mathrm{ARh}^{\prime}+\right)}$} & \multirow{2}{*}{1000} & before transfusion & 34.3 & 2670 & 0 & \multirow{2}{*}{490} & \multirow{2}{*}{390} & \multirow{2}{*}{+130} \\
\hline & & $20 \mathrm{hr}$. after transfusion & 38.3 & 3230 & 23 & & & \\
\hline \multirow{2}{*}{$\left(\mathrm{ARh}^{4}+\right)$} & \multirow{2}{*}{1460} & before transfusion & 35.4 & 3090 & 8 & \multirow{2}{*}{640} & \multirow{2}{*}{620} & \multirow{2}{*}{-170} \\
\hline & & $72 \mathrm{hr}$. after transfusion & 41.4 & 3140 & 39 & & & \\
\hline \multirow{2}{*}{$\stackrel{5}{(B R h+)}$} & \multirow{2}{*}{1100} & before transfusion & 32.4 & 3060 & 12 & \multirow{2}{*}{470} & \multirow{2}{*}{460} & \multirow{2}{*}{+80} \\
\hline & & $24 \mathrm{hr}$. after transfusion & 40.1 & 3160 & 34 & & & \\
\hline \multirow{2}{*}{$\stackrel{6}{(A)}$} & \multirow{2}{*}{1000} & before transfusion & 36.3 & 2760 & 1 & \multirow{2}{*}{390} & \multirow{2}{*}{340} & -70 \\
\hline & & 24 hr. after transfusion & 40.5 & 2780 & 22 & & & -10 \\
\hline 7 & $10 ? 0$ & before transfusion & 40.1 & 2940 & 47 & 12 & 350 & -10 \\
\hline & 1000 & $48 \mathrm{hr}$. after transfusion & 44.8 & 2880 & 57 & 720 & Sov & \\
\hline
\end{tabular}

* Calculated from plasma volume, hematocrit and percentage of non-agglutinable R.B.C. before and after transfusion. 
gest dose administered. The effects of these injections on the concentrations of plasma hemoglobin and serum bilirubin are illustrated in Figure 2.

It will be noted that, in common with the situation following the transfusion of incompatible red cells, and in contrast to the findings determined in cases receiving incompatible plasma, only minimal elevations of bilirubin concentration occurred in conjunction with relatively marked and sustained hemoglobinemia. The inference may be drawn, that the hemolytic process induced by the injection of incompatible plasma does not involve a rapid intravascular destruction of the recipient erythrocytes with the liberation of corresponding amounts of free hemoglobin into the free circulation, for the amount of bilirubin produced under these conditions is greater than could be accounted for, assuming its sole source to be the hemoglobin circulating in the plasma.
The hemolytic properties of incompatible group$O$ blood and pooled plasma.

Despite the infrequent occurrence of febrile reactions following the injection of incompatible isoagglutinins, it was suspected that asymptomatic hemolysis of recipient cells may be a common complication of this procedure. In order to evaluate this possibility and to determine quantitatively the degree of hemolysis produced, measurements of the blood volume, together with Ashby counts, were performed before and after a single transfusion of group-O whole blood in 7 recipients whose blood groups were A or B. None of these patients had experienced recent hemorrhage. All were battle casualties convalescing from chest wounds, with the exception of Case 1 , who was a patient with subacute glomerulonephritis.

The results of these studies are charted in Table II. It is evident that a significant degree

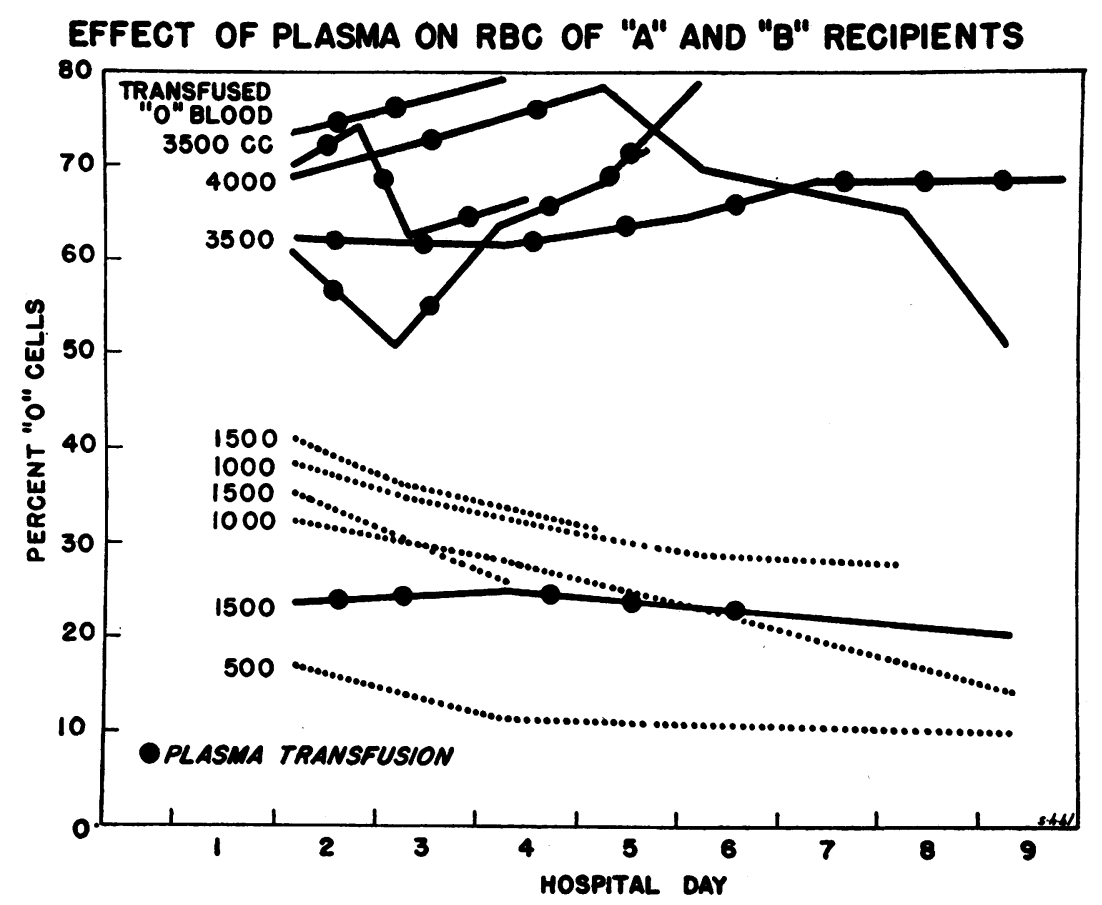

Fig. 3. The Destructive Effect of Repeated Plasma Transfusions on the Erythrocytes of Group-A and Group-B Recipients

All patients received an initial transfusion of stored group-O blood, the amount of which is indicated. The broken lines represent patients who received no further transfusions; the solid lines represent patients who subsequently received transfusions of pooled plasma, each transfusion being indicated by a dot. A progressive decline in the percentage of group-O cells is observed in the former group. An increase in this percentage indicates destruction of the recipient red cells, which is more rapid than the disappearance of the transfused cells in patients receiving pooled plasma. 
of blood destruction involving the recipient cells followed transfusion in Cases 1,2 and possibly 4 . Such variations as are noted in the other cases, with respect to the changes in red cell volumes, are within the limits of experimental error. It is noteworthy that in no case, including those in whom a considerable degree of blood destruction occurred, was transfusion followed by chills or fever.

Blood or plasma containing incompatible isoagglutinins appeared to have a more destructive effect when administered in multiple repeated transfusions, as evidenced by the results of a study in which serial Ashby counts were performed over a period of several days in patients of blood groups $A$ and $B$. The therapy in each case included an initial large transfusion of group-O blood, which had previously been stored for approximately two weeks. Whole blood transfusion was not repeated during the period of these observations. One group of patients received repeated plasma transfusions on successive days, while the other group, which served as the control series, received no plasma during this period. The results are illustrated in Figure 3.

It was observed that, in cases receiving no plasma transfusions, the percentage of group-O cells progressively declined from day to day, the rate of their disappearance being consistent with the expected rate of destruction of injected, 2weeks-old red cells. In contrast to the findings in these cases, however, those patients receiving repeated plasma transfusions failed to demonstrate the expected decline in percentage of group$O$ cells and, indeed, usually exhibited a persistent increase as long as this therapy was continued. It appeared, therefore, that the plasma recipients incurred a destruction of their own erythrocytes, which, in rapidity, equalled or exceeded that involving the transfused stored cells. More extended laboratory study of these patients, including serial measurements of the icterus index and hematocrit readings, demonstrated the development of progressive anemia and hyperbilirubine-

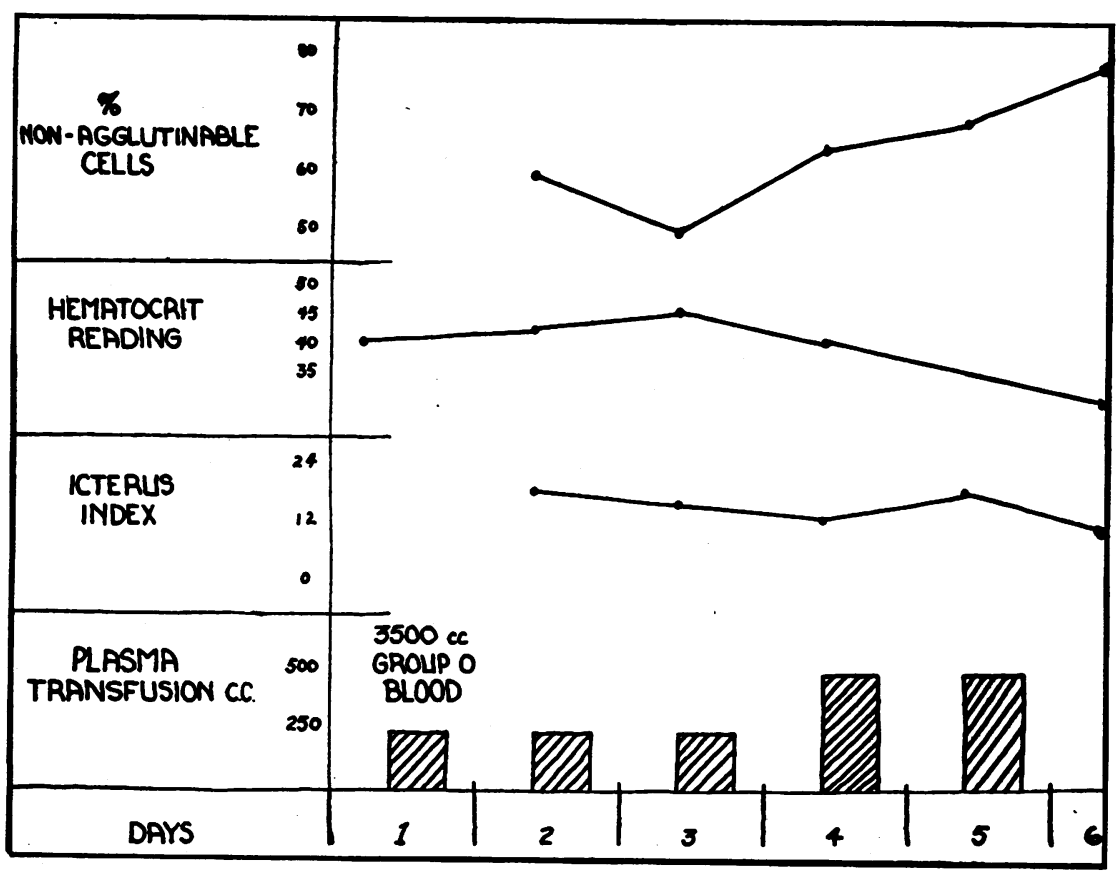

Fig. 4. The Hemolytic Effect of Pooled Plasma, Observed in One Patient of Blood Group A

This figure illustrates the course of the Ashby count, hematocrit reading and icterus index in a patient of blood group A who received repeated transfusions of pooled plasma. Note the increasing percentage of group-O cells, indicating that rapid destruction of group-A cells has contributed to the development of anemia and persistence of icterus. 
mia corresponding in degree with the severity of the hemolytic process as indicated by the Ashby counts (Figure 4).

Changes in the osmotic fragility of recipient erythrocytes following transfusions of plasma and whole blood containing incompatible isoagglutinins.

An unusual opportunity to study the effects of massive doses of pooled plasma on recipients of different blood groups was afforded in the course of observing 7 patients, who were treated for extensive gasoline burns. Three of these patients were of blood group-O. The burns were of comparable degree and extent in all cases, and all received large amounts of pooled dried human plasma, supplemented, in some instances, by group-O whole blood. Each patient received a local application of sulfanilamide powder as part of the initial treatment of the burn, but in no case were sulfonamides administered by mouth or parenterally, by injection.
One feature of interest was the finding of a definite increase in the osmotic erythrocyte fragility in all cases, with the exception of those patients of blood group-O. The fragility curves, determined 48 to 72 hours after injury, are charted in Figure 5, with a notation of the patients' blood groups (O), (A) and (AB), as well as the amount of plasma (P) and whole blood (WB) received prior to the test. Ashby counts, carried out in saline solutions of various concentrations, indicated that the increase in osmotic fragility involved only the recipient cells. The patient showing the most striking change in osmotic fragility (Figure 5) died on the 4th hospital day with an acute hemolytic anemia, progressively marked hemoglobinemia and hemoglobinuria having been present for 24 hours. In addition to $7000 \mathrm{ml}$. of pooled plasma, he had received $2500 \mathrm{ml}$. of group$\mathrm{O}$. whole blood prior to death; at that time his hematocrit reading was 24 , and 90 per cent of his circulating red cells were group-O cells, indicating almost complete destruction of his own erythro-

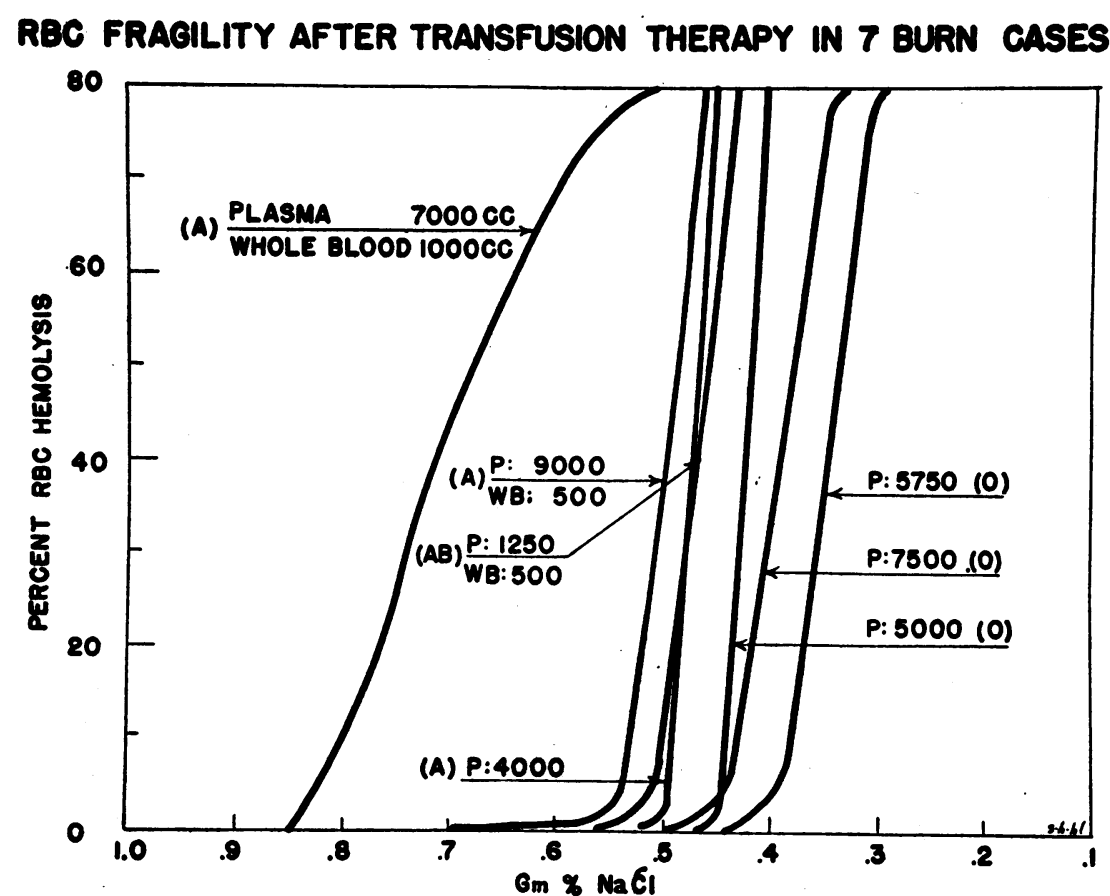

Fig. 5. Osmotic Erythrocyte Fragility After Transfusion Therapy in Seven Patients with Severe Burns

The blood group of each patient, together with the amount of plasma (P) and whole blood (WB) received, are indicated with each fragility curve. The whole blood used was exclusively group- $O$. Note the increased osmotic erythrocyte fragility in patients whose blood groups were other than group-O. 


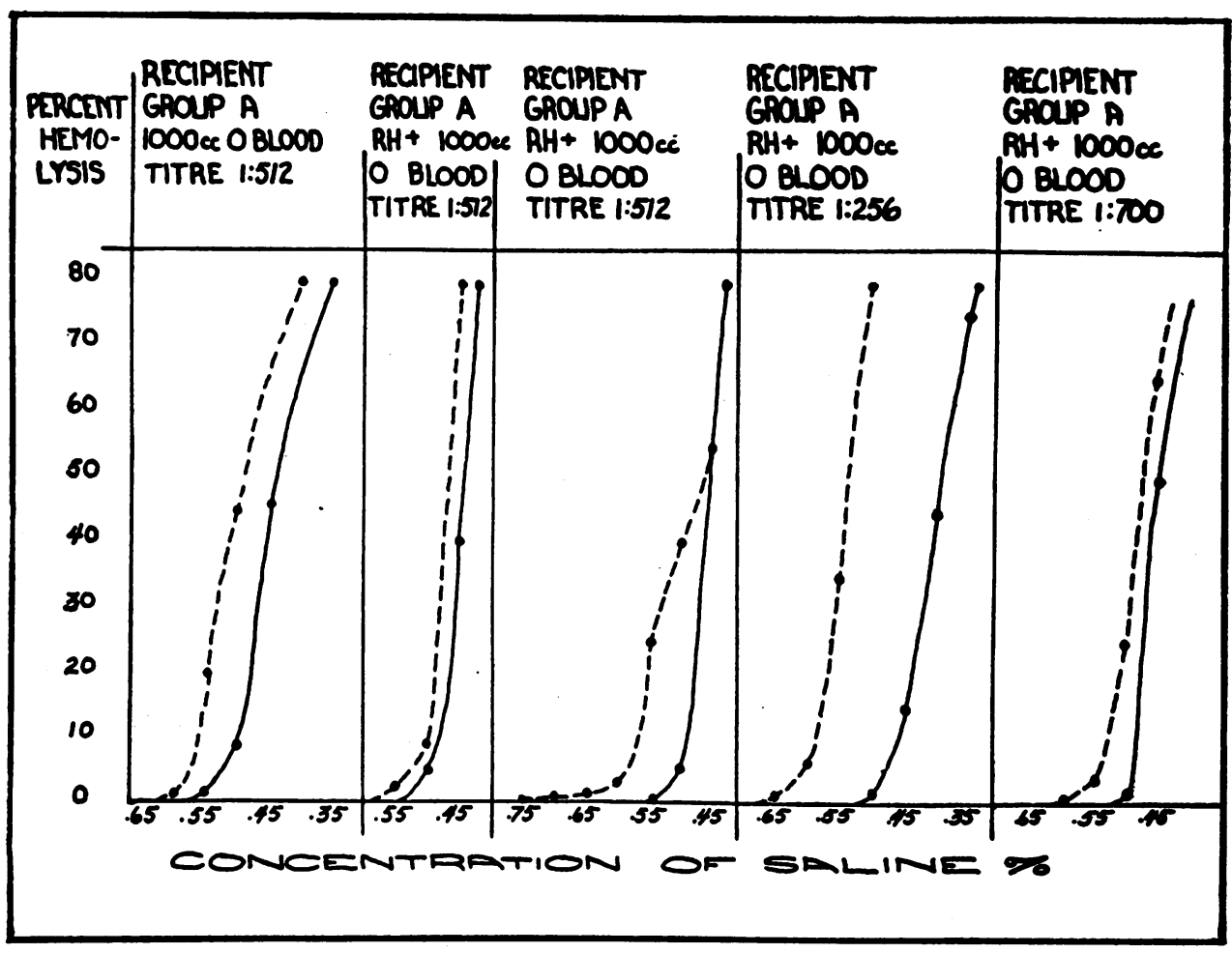

Fig. 6. Changes in Osmotic Erythrocyte Fragility in Patients of Blood Group A Following Transfusion of Group-O Blood Containing Anti-A Isoagglutinins in High TITER

The solid lines represent the osmotic fragility curves determined before the transfusion; the dotted lines, the fragility immediately following this procedure. The volume and isoagglutinin titer of the transfused blood are indicated in each case.

cytes. Combined Ashby counts and osmotic fragility tests further showed that all of his remaining group-A cells hemolyzed in concentrations of sodium chloride greater than 0.6 gram per cent, whereas the group-O cells, derived from transfusions, only began to hemolyze in solutions of less than 0.5 gram per cent sodium chloride. Another of the group-A patients demonstrated almost complete replacement of his own red cells by transfused cells, having received $10,000 \mathrm{ml}$. of pooled plasma and $6000 \mathrm{ml}$. of group-O whole blood in the course of 12 days. As in the case of the first patient described, his blood also exhibited a rapidly progressive increase in osmotic fragility affecting only his own red cells, as well as hemoglobinemia and hemoglobinuria for 2 days prior to death, which occurred on the 12 th day following injury.

In order to determine whether these changes in osmotic fragility were, in fact, attributable to transfusion therapy rather than to the effects of the burn itself, or to other therapy accorded these patients, serial observations were made of the red cell osmotic fragility of 12 patients of blood group$\mathrm{A} \mathrm{Rh}+$ before and after transfusion with group$O$ blood containing anti-A agglutinins in various concentrations. Seven patients who received blood, the anti-A agglutinin titer of which exceeded 1:200, showed a definite increase in osmotic fragility which was demonstrable promptly after transfusion. Five patients receiving agglutinins in lower titer showed no fragility changes; one of these, however, following a subsequent transfusion of low-titer blood, exhibited a markedly increased osmotic fragility of the red cells. Similar studies carried out on group-O recipients indicated that no change in osmotic fragility occurred in these individuals following transfusion.

The effect of transfusion on the erythrocyte osmotic fragility in 5 group-A recipients of group-O blood is illustrated graphically in Figure 6. The dotted line represents in each instance the fragility 
before transfusion, and the solid line the fragility determined immediately following its conclusion. All of the patients whose fragility curves are charted in this illustration had received previous transfusions of group-O blood and pooled plasma, which probably accounts for the deviations from the normal apparent in the pre-transfusion samples, inasmuch as similar abnormalities were never observed in individuals who had received no transfusions, or in patients of blood group-O. The irregular configuration of certain of these fragility curves is due to the fact that the blood examined contained a mixture of recipient cells and transfused group-O cells. This phenomenon of increased osmotic fragility of the red cells was demonstrable immediately following transfusion of blood containing a high concentration of incompatible agglutinins; the change was progressively more marked with repeated transfusions of this type; and, finally, the results suggested that red cells so affected remained abnormally susceptible to hemolysis in hypotonic solutions of sodium chloride until they eventually disappeared from the circulation.

\section{DISCUSSION}

It is concluded from these studies that the transfusion of pooled plasma or whole blood containing incompatible isoagglutinins may not be entirely a benign procedure. Unless these isoagglutinins are present in low titer, some destruction of recipient cells probably always occurs, which may be manifested solely by an elevation of serum bilirubin. The repeated administration of large amounts of group-O blood or pooled plasma to individuals whose blood groups are other than group-O, appears to result in marked and progressive destruction of the recipient's cells. This phenomenon is usually not accompanied by clinical symptoms such as are ordinarily associated with a transfusion reaction; therefore, except for the development of a variable degree of icterus and anemia, or failure of the anemia to respond to transfusion therapy as anticipated, the hemolytic process may be overlooked. That the destruction of red cells in such cases may be extensive has been illustrated by two cases with severe burns, in whom practically the entire red cell population had been replaced by group-O cells. Another example of this type, observed by the authors, was a patient with lepto- spirosis icterohemorrhagicae, in whom complete replacement of the recipient group-A cells with group-O cells could be demonstrated following multiple transfusions of pooled plasma and groupO blood.

The degree of hyperbilirubinemia following transfusions of incompatible plasma, as well as the promptness and constancy with which it was observed, was unexpectedly great in proportion to the development of hemoglobinemia. This evidence suggests that the major portion of blood cells destroyed by incompatible plasma is not hemolyzed in the free circulation, but in a site that is to some extent segregated, and in close proximity to the bilirubin-forming tissues. A similar situation may exist in certain naturally occurring hemolytic syndromes, for example congenital hemolytic jaundice, in cases of which hemoglobinemia is ordinarily absent, and in which hemolysis of the congenitally defective erythrocytes is presumed to take place chiefly in the spleen. Hemolytic syndromes attributable to hemolytic systems demonstrable in vitro, on the other hand, such as paroxysmal nocturnal hemoglobinuria and paroxysmal hemoglobinuria due to chilling, are characterized by hemoglobinemia, which is unaccompanied by significant hyperbilirubinemia. It is suggested that, in hemolytic diseases of the latter type, the erythrocytes are destroyed by the activated hemolysin intravascularly, as in the test tube, hemoglobin being liberated directly into the free circulation.

Dameshek and Schwartz (13) were able to produce hemolytic anemia in guinea pigs by injecting serum obtained from rabbits immunized against guinea pig erythrocytes. In large doses this serum, which contained agglutinins as well as hemolysins, produced marked hemoglobinuria and death; repeated small doses caused subacute anemia of moderate degree, without hemoglobinuria. With both schedules of dosage there resulted an increase in osmotic erythrocyte fragility. Evidence that corresponding effects may be produced in humans, following transfusion with incompatible plasma, is contained in the results of osmotic fragility studies reported in this communication. Thus, of 4 cases of blood groups $A$ and $A B$, who received massive quantities of pooled human plasma in the treatment of severe burns, all exhibited a progressive increase of osmotic erythrocyte fragility. It is to be noted that 
Shen and Ham (14) have described changes in erythrocyte osmotic fragility in patients with severe burns. However, it is considered that the fragility changes described in the cases studied in the present series are probably not related to a thermal effect, for the patients' red cells were almost totally involved, the fragility changes were progressive over a period of several days, and did not occur when the patients' blood was groupO. Moreover, fragility changes of an identical character were observed following single transfusions of blood containing a high concentration of incompatible isoagglutinins, and multiple transfusions with low-titer agglutinins, in patients who had sustained no burn.

The mechanism of the increased osmotic fragility exhibited by recipients of incompatible plasma is unknown. The salient features of the phenomenon, however, are evidently related to the presence of a specific immunologic property of the incompatible plasma, and not due to a complication of disease or injury, or to some fortuitous, non-specific effect of the transfusion. It is uncertain whether, in these cases, the increased susceptibility of the erythrocytes to hemolysis in hypotonic solutions of sodium chloride is a factor contributing to the hemolytic syndrome, or whether it is merely an index of. red cell damage.

With regard to the practical aspects of transfusion therapy, no evidence has been obtained which suggests that the emergency use of groupO blood, containing a low titer of isoagglutinins, may be attended with undesirable consequences. It is important, however, that stored group-O blood, before it is designated for this purpose, should be examined for the concentration of isoagglutinins contained in the plasma, as was done by the Army Blood Bank in the latter phases of the European campaign, high-titer blood being reserved for group-O recipients. On the other hand, in cases requiring repeated transfusions, blood of a homologous group should be administered, unless the method of Witbsky (15), designed to neutralize the isoagglutinin potency by absorption with purified $\mathrm{A}$ and $\mathrm{B}$ substances, proves entirely satisfactory and becomes generally available. Further evidence is required before the limitations of plasma transfusion can be adequately defined. A significant titer of isoagglutinins is frequently demonstrable in commercial brands of dried human pooled plasma, and observations suggest that, when this material is employed in massive dosage or administered repeatedly to patients whose blood groups are other than group-O, rapid blood destruction may result.

\section{SUMMARY AND CONCLUSIONS}

1. A study has been made of certain complications attending the transfusion of group-O blood and pooled plasma containing incompatible isoagglutinins. The investigation was conducted in a U. S. Army General Hospital and Evacuation Hospital, during the course of the European campaign.

2. Febrile hemolytic reactions, accompanied by chills, were rarely observed following either single or multiple transfusions of group-O blood into recipients whose blood groups were $\mathrm{A}, \mathrm{B}$ or $\mathrm{AB}$. Three reactions, accompanied by hemoglobinemia and hyperbilirubinemia, were observed in the course of 265 consecutive transfusions of this type, an incidence of 1.1 per cent. The isogglutinin titer of the blood implicated in these reactions in each case exceeded 1:500.

3. Studies, whch included serial Ashby counts and, in some instances, blood volume measurements, indicated that asymptomatic blood destruction involving the recipient cells was occasionally produced by single, and almost invariably by multiple, transfusions of pooled plasma or group$O$ blood, when administered to patients of other blood groups.

4. In contrast to the findings after the injection of cell-free hemoglobin solution, a disparity was noted between the degree of hyperbilirubinemia and hemoglobinemia produced by these transfusions. This suggested that most of the hemolysis produced by incompatible plasma does not occur in the free circulation.

5. An increase in the osmotic fragility of the recipient erythrocytes was frequently observed following transfusions of group-O blood and pooled plasma in patients of blood groups other than group- $\mathrm{O}$, the occurrence of this phenomenon being related to the concentration of incompatible isoagglutinins and frequency of their administration. 


\section{BIBLIOGRAPHY}

1. Rosenthal, N., and Vogel, P., Observations on blood transfusions from universal donors. Blood Substitutes and Blood Transfusion, Mudd, S., and Thalhimer, W., Editors. Charles C. Thomas, Springfield, 1942, Chapter XXX.

2. Aubert, E. F., Boorman, K. E., Dodd, B. E., and Loutit, J. F., The universal donor with high titer isoagglutinins. Brit. M. J., 1942, 1, 659.

3. Wiener, A. S., and Moloney, W. C., Hemolytic transfusion reactions; differential diagnosis; "dangerous universal donor" or intra-group incompatibility? Am. J. Clin. Path., 1943, 13, 74.

4. Weintraub, S., Transfusion reaction caused by a proven dangerous universal donor. Am. J. Clin. Path., 1943, 13, 315.

5. Malkiel, S., and Boyd, W. C., A transfusion reaction due to a dangerous universal donor. J. A. M. A., 1945, 129, 344.

6. Ashby, W., Determination of the length of life of transfused blood corpuscles in man. J. Exper. Med., 1919, 29, 267.

7. Bing, F. C., and Baker, R. W., The determination of hemoglobin in minute amounts of blood by Wu's method. J. Biol. Chem., 1931, 92, 589.
8. Kolmer, J. A., and Boerner, F., Approved Laboratory Technic. Appleton-Century Co., New York, 1945, p. 829.

9. Gibson, J. G., Jr., and Evelyn, K. A., Clinical studies of blood volume; adaptation of method to photoelectric microcolorimeter. J. Clin. Invest., 1938, 17, 153.

10. Emerson, C. P., Jr., and Ebert, R. V., A study of shock in battle casualties: measurements of the blood volume changes occurring in response to therapy. Ann. Surg., 1945, 122, 745.

11. Stead, E. A., Jr., and Ebert, R. V., Relationship of plasma volume and the cell-plasma ratio to total red cell volume. Am. J. Physiol., 1941, 132, 411.

12. Gibson, J. G., Jr., Unpublished data.

13. Dameshek, W., and Schwartz, S. O., Hemolysins as a cause of clinical and experimental hemolytic anemias. Am. J. M. Sc., 1938, 196, 769.

14. Shen, S. C., and Ham, T. H., Studies on the destruction of red blood cells. III. Mechanism and complications of hemoglobinuria in patients with thermal burns; spherocytosis and increased osmotic fragility of red blood cells. New England J. Med., 1943, 229, 701.

15. Witebsky, E., Klendshoj, N., and Swanson, P., Preparation and transfusion of safe universal blood. J. A. M. A., 1941, 116, 2654. 